\title{
Hegemony of the Ulu Apad Government System in Bali Aga Village (From Ancient Bali to Dutch Colonial Period)
}

\author{
I Wayan Pardi ${ }^{1}$, I Made Pageh ${ }^{1}$ \\ wayan.pardi@undiksha.ac.id, made.pageh@undiksha.ac.id \\ ${ }^{1}$ Universitas Pendidikan Ganesha, Indonesia
}

\begin{abstract}
The present study aims to analyze the origins of the Ulu Apad government system from old Bali to the Dutch colonial era. The theoretical frameworks underlying this study are village government system theory, hegemony theory, social organization theory, structural functionalism, and symbolic interaction theory. Meanwhile, the research method employed was the history writing method. The findings showed that Bali Aga Village was an old village inhabited by humans since prehistoric times and continued in the old Balinese era (VIII-XIV) up to the recently. Bali Aga village generally used the Ulu Apad government system. This system existed since the old Balinese period. After being conquered by Majapahit Kingdom (dated 1343 AD), there was hegemony in Bali towards the villages of Bali Aga by placing Majapahit/Gelgel representatives in the villages of Bali Aga. The study also discovered a change in Bali's power structure during the Dutch colonial rule. The king no longer occupied the top of the power hierarchy, but there was a controleur who supervised the king and was responsible to the assistant Resident, Resident, and Governor Generals of the Dutch East Indies as the top of the power hierarchy.
\end{abstract}

Key Words: History, Bali Aga, Government System, Ulu Apad

\section{Introduction}

Bali is known worldwide as the Island of a Thousand Temples [7]. Bali has long been a laboratory for world-renowned anthropologists, such as Margaret Mead and Gregory Bateson [2], Clifford Geertz, Henk Schulte Nordholt, and David J. Stuart-Fox. Balinese society studies play an essential role in increasing knowledge about Austronesian speaking and cultured communities in the Asia Pacific. Austronesian ancestors first migrated from South China to Taiwan, and from there spread over most of Southeast Asia, to Hawaii, Easter Island, and Madagascar [20]. In Bali, the people who speak and have Austronesian culture can mostly be found in mountainous areas.

The people who live in Bali Island can generally be grouped into two, namely the "Bali Aga" community and the "Bali Majapahit" community. The designation of the two groups of people is aimed to distinguish people who first came to Bali from those who came to Bali later [19]. The Bali Aga community is a group of people who came to Bali earlier, lived in villages in the mountains of Bali, and were less affected by the Majapahit Culture 
influence (Tim Penyusun, 1985: 12; [19]; Dharmayudha, 1995: 35; [13]; [24]: 94; Yudantini, 2018: 1; [21]. The people of Bali Aga are a community group that existed before the Kingdom of Majapahit conquered Bali. Meanwhile, the Bali Majapahit community is a group of people who arrived in Bali when Majapahit ruled Bali. They generally lived in plains areas (urban) and were mostly affected by Majapahit influence (Tim Penyusun, 1985: 12: [19], [13]; [24]

The culture of Bali Aga community is different from the culture of Bali Majapahit community (living in the plains area). The Bali Aga culture results from a syncretism between prehistoric culture (Austronesian culture) and Javanese Hindu culture. As a result, the culture has distinctive characteristics different from prehistoric culture, Hindu culture, or Bali Majapahit culture (Tim Penyusun, 1985: 17).

Bali Aga villages generally have their own governmental system called the Ulu Apad Government System [2]; [19]; [22]. Ulu Apad means climbing the ladder (Apad) to the top of the head (ulu) [19]. One of the most prominent features of the Ulu Apad Government System's promotion mechanism is the "queue system". This system limits any leaders not to precede each other in reaching certain positions because of their ambition or desire to get to the highest level quickly. The promotion should follow a natural process, such as age, marital status, or members quitting the organization.

Besides, Bali Aga Village or a village that implements the principle of Ulu Apad Government System is also considered an autonomous village, meaning that it is independent of one another, independent from the government, democratic in nature, has its laws, customary rules and traditions so that Bali Aga Village is often termed as "The Little Republic" [2] or Dorpsrepubliek meaning "Village Republic" [6]. Therefore, much of the religious, social, and political life of the people of Bali Aga Village is decided (only) in a session or council of village people (krama desa ulu apad) [20].

The form of such a village government system is the representation of the original Balinese village that existed before the rule of the Majapahit kings [2]. After Bali was controlled and ruled by the Majapahit kingdom, the village's situation began to change. However, Bali Aga people who rejected changes over their traditions and culture to experience a shift from being inherited by their ancestors exiled themselves in mountainous areas and formed the colonies of Bali Aga Village. In fact, several Bali Aga villages that did not want to acknowledge the Majapahit government in Bali started an uprising against the Majapahit kingdom [1].

After the colonization of Majapahit in Bali, the majority of ordinary people who were born in Bali and did not have Majapahit origins eventually became "outsiders" $($ Anak jaba). The highlanders were outsiders of their own choice. They were the Balinese who chose to continue their traditions in the mountainous areas and maintained their relationship with their ancestors, instead of embracing the Majapahit civilization and the imaginary ancestors considered higher [19].

The condition of the Bali Aga community above is conceptually described as people who were marginalized economically and socially, far from the culture of modern Balinese society, and was uncivilized. Therefore, many attempts were made to create a new sociocultural order for the Bali Aga society through strategies carried out by the elite of the modern Balinese government (Bali Majapahit). The most apparent intervention was the establishment of Badan Pelaksana Pembina Lembaga Adat [Enacting Agency for Trustees of Customary Institutions] and Parisada Hindu Dharma Indonesia make changes in the fields of tradition (adat) and religion in the Bali Aga community.

This condition certainly harmed the sustainability of the traditions and culture of the Bali Aga people. The culture inherited from previous generations must be confronted with the 
reality of renewal in practice (custom) and religion. [19] states that government intervention in the Bali Aga community is considered to have originated from "... an old enemy with a new veil" or borrowing [6] idea, the intervention "... is nothing more than a parasite from outside."

With this in mind, scientific research is necessary to carry out an inventory of the Bali Aga people's cultures. Besides aiming to find out the diversity of Bali Aga culture, this study also strives to maintain the "Republic of Bali Aga" against the sovereignty of "Bali Majapahit State" (Majapahit culture). Based on the above background, the present study aims to analyze the origins of the Ulu Apad government system from old Bali to the Dutch colonial era. In this research, theoretical frameworks are the village government system, hegemony theory, social organization, structural functionalism theory, and symbolic interaction theory.

\section{Methods}

\section{Heuristics (Data Collection)}

Heuristics collects sources, data, and historical traces [10]. In this study, there were two types of data used: written data/documents and unwritten/artifact data. The written document/source data that the authors used in this research included document translation of inscriptions, translation of chronicles, books, articles, research reports, and other written sources related to the title of the article. Meanwhile, the unwritten data/artifact used were ancient relics in the form of prehistoric and historical relics such as Megalithic statues, Menhirs, Punden Berundak (stepped pyramid), Sarcophagi, and Bale Lantang / Bale Ulu Apad building in Pakraman Selulung village.

\section{Source Criticism}

After both written data/documents and unwritten/artifact data were garnered, the next step was conducting source criticism or verification. It consisted of two types, namely external criticism, testing the authenticity of sources, and internal criticism, testing the credibility or trustworthiness of the collected data [10]. The data used in writing history (historiography) can be scientifically justified through these two source criticisms.

\section{Interpretation}

Interpretation refers to the technique of interpreting data [10]. There are two types of interpretation, namely analysis, and synthesis. Analysis means describing the data so that the author could find facts. Meanwhile, synthesis means bringing together the facts discovered and grouping them with conceptual generalizations [10]; [17]. The interpretation also allows the researchers to select historical facts because not all points could and should be included in historical writing.

\section{Historical Writing}

Historical writing (historiography) is a way of presenting or writing history based on the research that has been done [18]. In writing history, the main formula that must be mastered is $5 \mathrm{~W}+1 \mathrm{H}$. Besides, to get a clear and systematic historical writing requires the principle of chronology (the time sequence of events) [10], the focus of sequencing (how to make sequences of events), the principle of causation (causal relationship), and the principle of colligation (connecting facts that are intrinsically and give meaning to all past events to be built). The principle of imagination is also used to make analogies between past events and actions in the present.

\section{Results And Discussion 1. Ulu Apad Government System in Old Bali}


Tracing the period when the village government system established in Bali villages was complicated because of the lack of historical records. However, based on the inscription records, it could be seen that the village government system existed since the old Balinese era [2]. The arrangement of the administrative area during the old Bali kingdom consisted of central and village level areas. The mid-level area covered the entire territory of the Kingdom called kedatwan/kedatuan. During the old Balinese Kingdom, the position and power of the king occupied the highest hierarchy. The king was, in principle, a very noble, great figure and should be used as an example/role model. [2] mentioned several positions under the king, namely senapati, samgat, Siwa/Hindu priest and Buddha, dhikara, ser, nayakan, cakuu, sahaya, juru, hulu, tuhan, paramadhyastha, sthapaka, and ademmak/demak.

Meanwhile, the village level territorial area was referred to by several terms in the inscription. The first was the term Wапиа or Banua, which means village (Bebetin AI Inscription, Bwahan A Inscription dated 916 Caka / 994 AD, Sading A Inscription dated 923 Caka / 1001 AD, Sembiran A III Inscription dated 938 Caka / 1016 AD, and the inscription of Bebetin A III dated 972 Caka / 1050 AD). The term Thani which means the rural area (Inscription of Bwahan dated 916 Caka / 994 AD, Batur Pura Abang Inscription dated 933 Caka / 1011 AD, Bebetin A III Inscription dated 972 Caka / 1050 AD, and the Sawan Inscription dated 975 Caka / 1053 AD. There was a term desa, which means village or region (Batuan inscription dated 944 Caka / 1022 AD and Ujung Inscription). Besides these terms, the term karaman was also found meaning village with legal unity or a group of people. Based on the sentence's context in the karaman inscription, it also means village leaders or villagers. Meanwhile, the whole village population was referred to anak wanua / anak banua, anak thani or tanayan thani [2].

After a position at the royal level was described, the inscriptions also mentioned positions at the village level whose positions were considered lower than those at the central/royal level. Its duties and authority were limited to the village area, the smallest territorial unit of the Kingdom. They were given the task of dealing with the village environment's problems. If the issues could not be resolved at the village level, they forwarded those problems to the king [2]. What mostly appears at the village level, as mentioned in Old Balinese inscriptions was Kabayan or Kubayan. In the Ulu Apad government system, generally found in Bali Aga villages today, Kabayan or Kubayan or Jero Bayan was the highest position (top leader) in the Ulu Apad government system.

The term Ulu Apad means the process of increasing the rank of members of the assembly (karaman, from the word rama, which means father) to the highest level or village leader/priest (with the general honorific title jero, which means insider) [2]; [19]: 328). Ulu apad means climbing the ladder ( apad) to the end of the head ( $u l u$ ). Concerning the longhouse architecture or bale lantang located in all Bali Aga villages, the term apad refers to wooden planks between several posts that divided the rectangle on the bale lantang. The seat of the Kubayan / Kabayan (the person with the highest position in the Ulu Apad government system) was given a seat next to the head (ulu) [19].

Clearer information about the position of Kubayan / Kabayan or Rama Kabayan can be found in the Sawan A = Belantih A inscription (dated 980 Caka / 1058 AD), as follow:

"In the year of Caka 980, the month of Magha on the 2nd, cuklapaksa, hariyang, umanis, caniscara, wara balamukti, on that day there were several villagers in Sukhapura as conquered areas, Harangan village, Gurguran village, Bangli village, especially Sukhapura village. Sahaya (named) Mahintin, his clerk (named) Citrangca, Kubayan Father (named) Father Limacri, Karaksayanya (named) Dharmacri, met His Majesty King Anak Wungsu on behalf of Bhatari who was bathed in Burwan and 
Bhatara who was bathed in Air Wka, especially the masters (and) Bhagavata Mahananda."

The Sukawana A II inscription (dated 976 Caka / 1054 AD) also mentioned the position of Rama Kabayan named Dang Acaryya Tatpurusa who went to the king to ask for grace 18. Inscription Bwahan A (dated 916 Caka / 994 AD) also contained the identity of Rama Kabayan named Dang Acaryya Dewanggi and Badra meeting King Udayana [23]. The Cempaga C inscription (dated 1246 Caka / 1324 AD) contained the identity of Rama Kabayan consisting of a Kabayan Arga named Bapa Ringed, Kabayan Tngah named Bapa Nganter, Kubayan Noman named Bapa Mtus. The Sukawana D inscription (dated 1222 Caka / 1300 AD) also provided a more varied picture of the kabayan positions consisting of Kabayan Arga, Kabayan Tuha, Kabayan Tnah, Kabayan Noman (Wirtawan, 2013: 239). The positions of some of the Kabayan could still be found in Sukawana Village, but not completely as stated in the Sukawana D inscription. The Kabayan positions in Sukawana Village were now only Kabayan Mucuk and Kabayan Kiwa.

Besides the Kabayan position found in several inscriptions above, the Batur Pura Abang C inscription (dated 1306 Caka / 1384 AD) mentioned the names of positions in Her Hwang village (Abang Kintamani Village). Those positions consisted of Kabayan Tuha and Kabayan Noman, Argga Tuha and Argga Noman, Bahu Tuha and Bahu Noman, Panghet Tuha and Panghet Noman [3]. The exciting thing about the contents of the inscription above was that currently, in the Ulu Apad government structure, the position of the bahu / kubahu / Jro Bau was under Kubayan / Kabayan. For example, the following is a chart of the Ulu Apad government system's structure in Sukawana Village and the Ulu Apad government system in Pakraman Selulung Village.

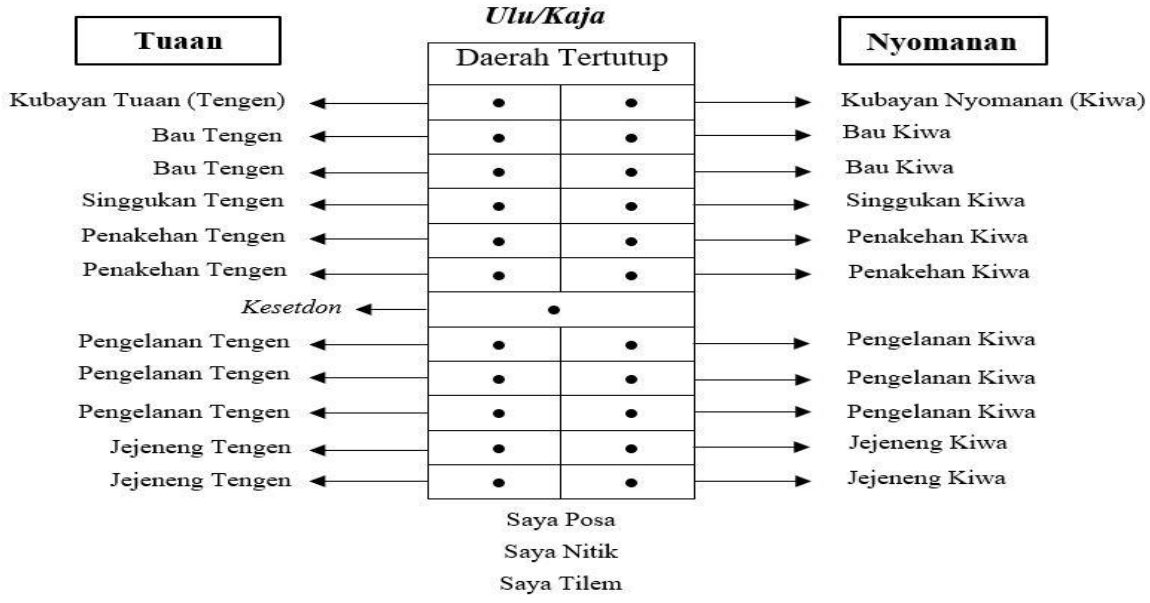

Fig 1. Ulu Apad Government System In Sukawana Village, Kintamani District, Bangli Source: Reuter (2005: 330)

According to chart 1., it can be seen that Ulu Apad Kubayan Mucuk and Kubayan Kiwa occupy were the highest positions in the governmental structure. Wirtawan (2013: 239240) explains that the task or authority of Kubayan Mucuk was to regulate all kinds of social and religious activities in Sukawana Village and act as the highest leader in the Ulu Apad structure. It had the authority to decide everything in deliberation and religious rituals. Meanwhile, the task or power of Kubayan Kiwa was the companion to Kubayan Mucuk and 
served as a clerk or secretary. In social activities, Kubayan Kiwa recorded all ongoing social activities in Sukawana Village. Kubayan Kiwa was required to direct or regulate them in religious activities. The task of Kubayan Kiwa became more manageable with the help of Kubayan Mucuk.

The structure of the Ulu Apad Government in Sukawana Village above was also found closely similar to that in Pakraman Selulung Village, Kintamani District, Bangli.

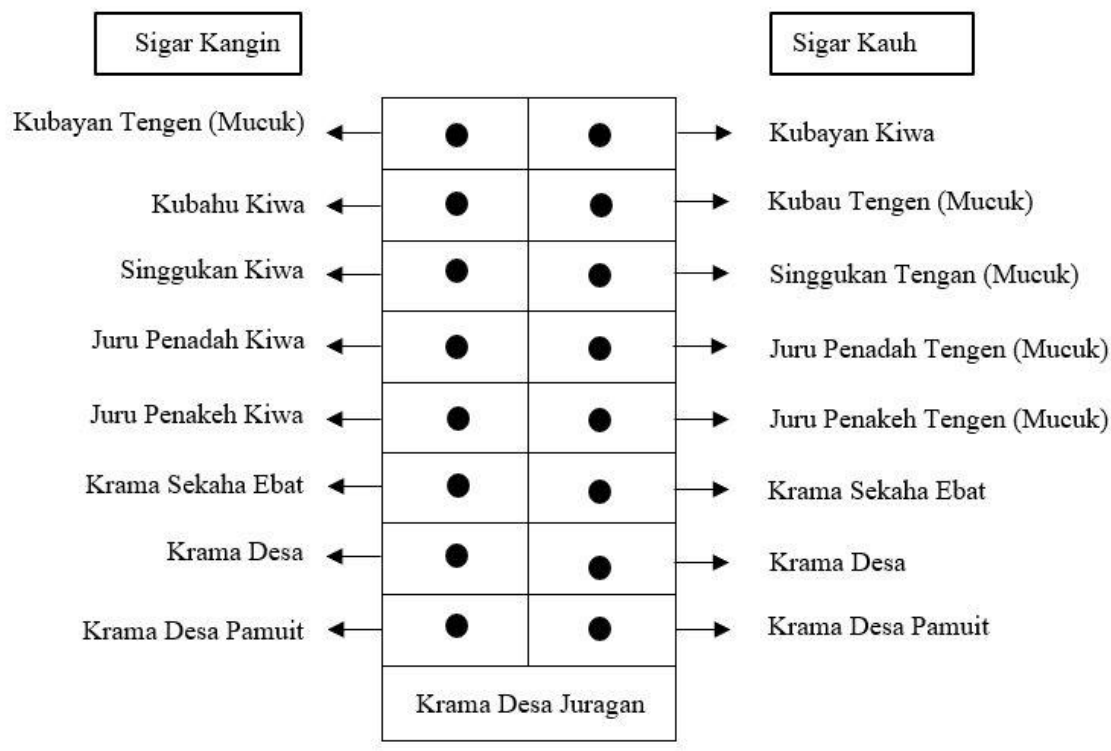

Fig 2. Ulu Apad Government System In Pakraman Selulung Village, Kintamani District, Bangli

According to Chart 2., it can be seen that the Ulu Apad structure in Pakraman Selulung Village consisted of 8 (eight) layers. Each layer comprised of pairs (sahing) left (kiwa) and right (tengen), called kangin sigar and kauh sigar. Half of the Ulu Apad structure went to the "left side" (sibak kiwa or sigar kauh) and sat on the left, while the other half entered and sat on the "right side" (sibak tengen or sigar kangin). Sigar Kangin and sigar kauh were grouped from Krama Desa Pamuit, Krama Desa, Sekaha Ebat, Juru Penakeh, Juru Penadah, Singgukan, Kubahu and Kubayan. Each pair had its place at the meeting hall at Bale Agung. Meanwhile, Krama Desa Juragan was a krama jangkepan (husband-wife) who did not have a seat (upright) or did not enter the Ulu Apad government structure and was a person who had left the Ulu Apad organization.

\section{The Hegemony of the Village Government System after the Conquest of Majapahit}

The Majapahit attack on Bali became the culmination of a series of unharmonious relations between Java and Bali [25]. Kekawin Nagarakertagama recounted the attack was led by Prime Minister Gadjah Mada in 1265 Caka or 1343 AD during the reign of King Tribhuwanottunggadewi Jayawisnuwarddhani (dated 1250-1272 Caka) of the Majapahit Kingdom. Bali in the IX-XIV centuries was a unitary kingdom that was sovereign, 
autonomous, and running its government apart from bureaucratic ties with other kingdoms. Bali's conquest by Prime Minister Gadjah Mada in 1343 AD not only lowered Bali from an independent kingdom to a conquered / colonized kingdom but also impacted the socio-cultural field of Balinese society [25]. The conquest was then constructed as the beginning of Hindu civilization in Bali, and the occupation of Bali Aga was constructed as a remnant of Bali's uncivilized past [19]. In the same vein, [7] described:

"The conquest of Bali by Majapahit was considered (even today) to have erased Bali's previous history because it cut down the animal barbarism period in old Balinese society and turned it into Bali which was full of elegant aesthetics and the order of the years of liturgical rituals".

"It was Majapahit at first, whatever existed before it was just a chaotic world controlled by demons and bad people" was the view of most Balinese (aristocratic descendants/Majapahit refugees or who claimed to be descendants of Majapahit nobility) [8]. Such narratives could be found in traditional Balinese historical, literary works, such as in Babad Usana Bali Pulina. This view ignored the historical fact that a Hindu-Buddhist kingdom had developed in Bali for more than 600 years before the Majapahit Kingdom conquest in Bali [19]. The remains of old Balinese civilization could even be found in almost all of Bali Island.

Furthermore, the discrediting of the old Bali Kingdom (along with its society and culture) was also recorded by Mpu Prapanca in Kakawin Nagarakertagama Pupuh 49 stanza 4 when there was an attack on Bali by the Majapahit army as follows:

"Muwah rin Cakabdhesu masaksi nabhi,

ika bali nathanya dussila niccha,

dinon in bala bhrasta sakweh winasa,

hares salwir in dusta mandoh wisata".

Translation:

"Then in the Caka year, the issue of masaksi-nabhi (dated 1245 Caka / 1343 AD), in Bali, the king had ill-manner and humble,

attacked with troops, crushed, overpowered,

fear of all forms of bad, move away quickly" [4].

The depiction in the Kakawin Nagarakertagama which called the Balinese King was immoral and unconscionable was a provocation to discredit the Balinese King. The efforts to discredit the Balinese King continued to the literary works later. In Usana Bali by Dang Hyang Dwijendra from the end of the 15th century, it was stated that the King of Bali was a giant named Maya Denawa who was likened to the King of Bedahulu, namely Denawa, the King with the Head of Bali. Meanwhile, the Majapahit army was compared to a divine army under the leadership of Dewa Indra (bahasa inggrisnya prof), who was powerful. The name of King Bedahulu with the head of a pig was Majapahit strategy to establish supremacy of the Bali kingdom by using historical, literary works. Therefore, according to [25] such a narrative needed to be straightened out because what was meant by Bedahulu was the ideological difference between the King of Bali and the King of Majapahit, meaning that the King of Bali did not want to admit the greatness of the King of Majapahit.

Meanwhile, in Usana Bali by Dang Hyang Dwijendra, the Majapahit army under the leadership of Prime Minister Gadjah Mada and assisted by several Arya as warlords including Arya Damar, Arya Kenceng, Arya Kutawaringin, Arya Sentong, Arya Belog, Arya Kanuruhan, 
and several other Arya attacked Bali from various ways. Facing the Majapahit invading forces, the Balinese troops gave quite fierce resistance with a very tough warlord. To end the war, the Majapahit troops used cunning tricks by deceiving and captivating Pasung Gerigis, the Balinese troops' highest force [25].

By the death of the King of Bali, Sri Asta Sura Ratna Bumi Banten, Bali came under Majapahit's control. It seems that after the defeat of Bali, Majapahit did not immediately place a representative as a ruler in Bali. In the Babad Dalem, it was stated that in 1274 Caka or 1352 AD, Majapahit had just put a Duke in Bali who had the designation as Dalem Ketut Kresna Kepakisan. Counted from the year of the conquest of Gadjah Mada troops (dated 1265 Caka or 1343 AD) with a Duke in Bali (dated 1274 Caka or 1352 AD), there was a vacuum of leadership or king for nine years. The Balinese used the nine years of the vacuum to gather forces such as an underground movement to oppose Java's new ruler.

Information obtained from historical sources of traditional historiography such as Babad Dalem, Pamancangah Dalem, Babad Pulasari, and several other chronicles, it was described that during the early days of Majapahit rule, there were troubles throughout the island of Bali. There were rebellions in the mountainous villages as an expression of dissatisfaction with the new ruler from Java. In Babad Dalem, it was stated as follows:

"The rebellion (resistance) of the Bali Aga villages was spearheaded by the villages of Batur, Cempaga, Songan, Abang, Pinggan, Muntig, Pludu, Cintamani, Serahi, Manikliyu, Bonyoh, Katung, Pisang, Taro, Bayan, Sikawana. This was also followed by villages in the eastern and northern parts such as Culik, Tista, Margatiga, Garbawana, Got, Sekulkuning, Gariten, Lokasrana, Pwahan, Bulakan, Paselatan, Tukad Kaliki, Nobayu, Mrita, Tegal Langlangan, Bunut Empak, Datah, Muntig, Watudawa, Turamben, Simbaten Caniga Samlak, Kadampal, Dukuh Juntal, Carutcut, Bantas, Kutabayem, Watuwayang, Asti, Bluhu, Bonyoh, Presandaya, Jatituhu, Darmaji, Tambakung, Ban, Panek, Pedahan, Datah and other villages surroundings "([2].

In addition, the information garnered from traditional historiography, which mentioned that Bali was in an agitated situation, was in line with the inscription information. The inscriptions in question were the Tamblingan Inscription (dated 1306 Caka), Batur Pura Abang C Inscription (dated 1306 Caka), and the Gobleg Pura Batur C inscription (dated 1320 Caka). When examined in terms of language, the three inscriptions were very similar to Majapahit inscriptions, such as Biluluk I, Renek, Patapan I, Karang Bogem, Katiden, and Biluluk II inscriptions 25.

The Gobleg Pura Batur C inscription (dated 1320 Caka) seemed to be a repetition or reaffirmation of the Tamblingan inscription (dated $1306 \mathrm{Caka}$ ). The contents of the two inscriptions were similar; the first inscription did not mention the king's name, while the second inscription mentioned the name of the king who died. The contents of the two inscriptions described that Bali's condition was not peaceful. The life of a group of iron craftsmen or blacksmiths living around Tamblingan lake was disturbed by Arya Cengceng's actions. Thus, the blacksmiths left Tamblingan so that the king ordered the blacksmiths to return to Tamblingan. However, the king's order did not get any responses from the blacksmiths. Meanwhile, the Batur Pura Abang C inscription (dated 1306 Caka) described the disharmony between the two neighboring villages, namely Pemuteran and Her Abang Villages. Through the inscription's determination, it was hoped that the relationship between the two villages could be restored to normal [25] 
According to [25]: 44), the repetition of the same command in the Gobleg Pura Batur $C$ inscription (dated $1320 \mathrm{Caka}$ ) on the Tamblingan inscription (dated 1306 Caka) indicated the Duke of Bali at that time, namely Dalem Ketut was the substitute for Dalem Kresna. It was the beginning of his reign at that time. Perhaps, it was a period of consolidation or a transition period for moving the center of government from Samprangan to Gelgel.

In the XVI century, there was a large colonization of Bali's Majapahit people due to the Majapahit Empire's collapse. Some of the Majapahit people who were still loyal to Hinduism moved to Bali to avoid Islam's influence in Java [9]. The conquest of Majapahit and the colonization of Majapahit gave birth to dualism in Balinese identity, namely Bali Aga and Bali Majapahit [26]. The Bali Aga people were considered not to have a caste system or downgraded to become ordinary people (the Sudra caste) due to losing the war. The caste system consisting of the Brahmin, Kshatriya, and Vaisya castes only applied to the Bali Majapahit society, which was dominated by Javanese aristocrats. In subsequent developments, the caste system or social stratification of Balinese culture became increasingly complicated. The caste system developed into a very closed system of Wangsa (group) and soroh, so it did not allow for vertical social mobility. The Bali Aga people had little choice but to accept Majapahit's political domination.

Majapahit's influence also entered the village political system. The king began to place his representatives in the village. Perhaps there was a concern that the villages of Bali Aga would fight against the colonial rulers of Majapahit again. Old village figures who wanted to submit to the Majapahit government were awarded as leaders involved in overseeing the village's condition. The royal government structure was built with the king at the top of the system, then under him, there was the governor/deputy king, and the next position was the retainer. Meanwhile, some representatives could monitor the village's condition and provide reports to the king, namely bendesa / pembekel.

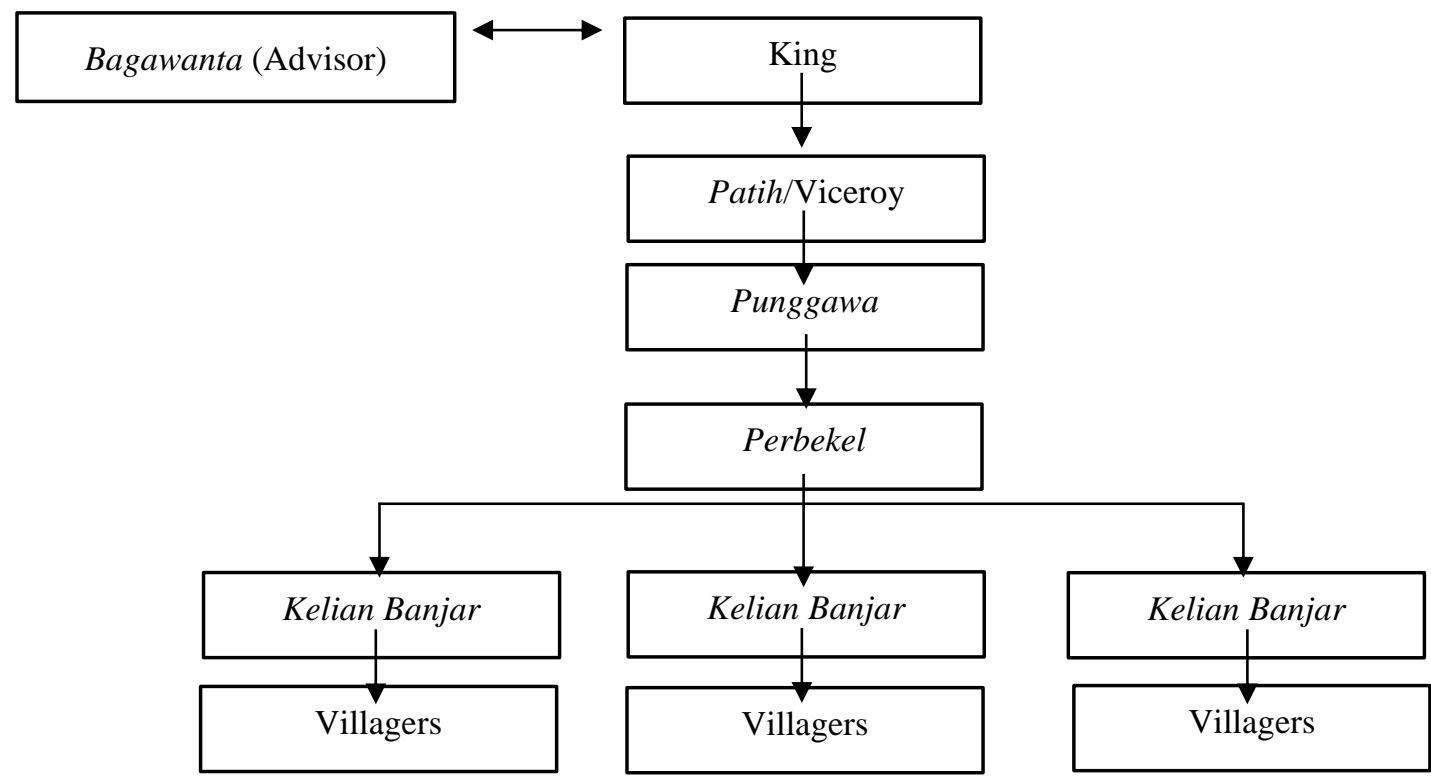

Fig 3.Traditional Government Structure during the Majapahit Period in Bali Source: Purna, et al (1997: 1) 
Above described the royal government structure from the top to the bottom/village levels. In this structure, the king was the top leader, assisted by several officials from within the palace [16]. The king was the owner of power throughout the Kingdom, so it was not surprising that the king had enormous and absolute authority in the society. All government administration activities were centered in the palace [15].

In carrying out government politics, the king appointed an advisor from the Brahman group, namely a Ciwa priest or a Buddhist priest with the designation Bagawanta / Bhagawannta [4]; Raharjo et al., 1998: 36). According to the Javanese tradition, poets took care of literature, history, philosophy, religion, and even time calculations for various purposes.

The king was also assisted by patih (Viceroy) who acted as deputy king and sometimes also held a warlord position to carry out his daily duties in government. The position of the patih became the representative of the king so that the governor could determine the political positioning of the Kingdom concerning foreign and domestic politics (Tim Peneliti dan Pencatatan Kebudayaan Daerah Bali, 1977: 8). To maintain the power, the positions of patih (Viceroy) and other top-level rulers such as punggawa were always taken from among the royal family or aristocratic descent (gusti) as the personal choice of the ruler, so that the ruler could personally fire and replace him [6].

The government structure under the patih level was punggawa. A punggawa was obliged to assist the king in government, and sometimes he could also help in customary and religious affairs in his territory. Seen from the hierarchy (line of command), a king could immediately give orders to a retainer and vice versa; a courtier was directly responsible to the king. It caused the position of the retainer in traditional society to be relatively high.

At the regional level, a punggawa was assisted by several specialists (now the Village Head) who governed the village territory, which was based on government at the regional level [16]. At the beginning of the reign of foreign kings in Gelgel, Pasek and Bendesa were sent to Bali Aga villages to monitor the village condition. [11] stated that the perbekel was the representative of the king in the village. [16] also exlained that the leadership structure in village level that helped the running of the royal government was called parbakal or purbakal. Thus, it appeared that the influence of foreign kings' power reached the village level; at least the king's supervision of the village could be carried out with the role of bendesa or pasek. The opinion above was also coined by the explanation from [12] that in the Majapahit era, there was hegemony towards the villages of Bali Aga by creating gelgel (Majapahitisasi) the villages of Bali Aga, namely by placing gelgel representatives in the villages of Bali Aga, such as Pasek Gelgel in Songan, Pasek Gelgel in Sukawana, Ngurah Watu Lepang in Gobleg and so on. The Gelgel representative's power was included in the Ulu Apad power structure in the village of Bali Aga; it was just that the position of the perbekel (bendesa) passed down from generation to generation in the Ulu Apad structure in the Bali Aga village.

Meanwhile, the villages with the Ulu Apad government system continued to carry out their organization's system as they should be. Therefore, since the Majapahit colonial rule in Bali, the villages of Bali Aga started to implement a dual system in their government, namely, on the one hand, implementing the Ulu Apad government system and on the other hand also implementing the complexion system, which emerged as an effort to hegemony the Majapahit power [2].

\section{The Existence of the Village Government System during the Dutch Colonial Period}


After being conquered by the Dutch (1908), Bali was divided into eight governments/kingdoms, namely Klungkung, Karangasem, Gianyar, Bangli, Badung, Buleleng, Tabanan, and Jembrana. In the Dutch colonial government structure, the King was no longer at the top but a resident in charge of the Bali and Lombok regions (kingdoms). This resident was directly responsible to the Governor-General of the Dutch East Indies, who was domiciled in Batavia. Under the resident, there was also an assistant resident. The Dutch colonial government divided Bali into two administrative areas, namely North Bali consisting of Buleleng and Jembrana under the resident's control in Singaraja, and South Bali consisting of Badung, Tabanan, Gianyar, Karangasem, Klungkung, and Bangli controlled by the assistant Resident in Denpasar. Meanwhile, in each of the Kingdom's territories, a controller was placed a Dutch colonial civil servant [8].

Furthermore, under the governmental structure of the kings, there were districts headed by Punggawa. Under the Punggawa was Perbekel, who led the newly formed villages by the Dutch colonial government. These new villages became known as the official villages (dienst). The term dienst village distinguished it from the old village that existed before and was also headed by a Perbekel. The old village that lived before the Dutch colonial government was then called the traditional village. The traditional village was governed by a traditional village head who later became known as Bendesa or Kelian Desa. In contrast, the official village (dienst) was headed by the official village head or more popularly known as Perbekel [8].

[17] also explained that the Dutch colonial government system was divided into two categories, namely Nederlandsche Bestuure or binnenlands bestuur (Dutch government), and Inheems Bestuure or landschap (local government). The following was the structure of the Dutch colonial government in Bali.

Table 1. Hierarchy of Government during the Dutch Colonial Period in Bali

\begin{tabular}{ccc}
$\begin{array}{c}\text { Government } \\
\text { Hierarchy }\end{array}$ & $\begin{array}{c}\text { Binnenlands Bestuur } \\
\text { (held by the Dutch) }\end{array}$ & $\begin{array}{c}\text { Landschap } \\
\text { (held by the Balinese) }\end{array}$ \\
\hline I & Resident & - \\
II & Asisten Resident & - \\
III & Controleur & Regent (Raja Bali) \\
IV & - & Punggawa \\
V & - & Perbekel \\
VI & - & Klian \\
\hline
\end{tabular}

Source: Raharjo, et al (1998: 45)

The government structure above did not change when the Japanese government replaced the Dutch colonial government. The only difference was in terms of the positions adjusted to the Japanese system. The following is the structure of government during the Japanese occupation on Bali.

Table 2. Hierarchy of Government during the Japanese Period in Bali

\begin{tabular}{ccc}
\hline $\begin{array}{c}\text { Government } \\
\text { Hierarchy }\end{array}$ & $\begin{array}{c}\text { Japanese Government } \\
\text { (held by the Japanese) }\end{array}$ & $\begin{array}{c}\text { Local Government } \\
\text { (held by Balinese) }\end{array}$ \\
\hline I & $\begin{array}{c}\text { Choo Kan } \\
\text { II }\end{array}$ & Ken Kan Rin Kan \\
III & Bun Ken Kan Rin Kan & - \\
IV & - & Syu Cho (Raja Bali) \\
Punggawa
\end{tabular}




\begin{tabular}{ccc}
\hline $\mathbf{V}$ & - & Perbekel \\
VI & - & Klian \\
\hline
\end{tabular}

Source: Raharjo, et al (1998: 46)

\section{Conclusion}

The Ulu Apad government system has existed since old Balinese times (VIII-XIV centuries), which was marked by the name Kubayan on the Sawan A = Belantih A Inscription (dated 980 Caka / 1058 AD), the Sukawana A-II inscription (dated 976 Caka / 1054 AD), Bwahan A Inscription (dated 916 Caka / 994 AD), Cempaga C Inscription (dated 1246 Caka / 1324 AD) and Sukawana D Inscription (dated 1222 Caka / 1300 AD). In the villages of Bali Aga, the Kubayan position was the highest in the Ulu Apad government system. After the colonization of Bali by Majapahit Kingdom (1343 AD), there was hegemony over the villages of Bali Aga by placing Majapahit or Gelgel representatives (bendesa) in Bali Aga villages, such as Pasek Gelgel in Songan, Pasek Gelgel in Sukawana, Pasek Gelgel in Selulung, Ngurah Watu Lepang in Gobleg and so on. This situation is an attempt to derail (Majapahitisasi) the villages of Bali Aga by placing bendesa positions in the Ulu Apad government system. As a result, Gelgel in the Ulu Apad government structure can be found up to recently because it has been passed down from generation to generation. Meanwhile, during Bali's Dutch colonial rule, the king no longer occupied the top of the hierarchy power but here was a controller (controleur) in charge of the king and had responded to the assistant resident, resident, and governor-general of the Dutch East Indies as the top of the hierarchy power.

\section{References}

[1] Ardhana, I K. 1994. Bali Dalam Kilasan Sejarah [Bali in a Glimpse of History]. Dinamika Masyarakat Dan Kebudayaan Bali [In Dynamics Society and Bali Culture]. (Editor: I Gde Pitana). Denpasar: Ofset BP, hh. 17-43

[2] Ardika, I W. dkk. 2015. Sejarah Bali: Dari Prasejarah Hingga Modern [History of Bali: From Prehistory to Modern]. Udayana University Press: Denpasar

[3] Atmodjo, S. K. 1987. Benda Purbakala Dari Pura Tulukbiyu Di Bali [Archaeological Objects From Tulukbiyu Temple in Bali]. Jurnal Berkala Arkeologi, vol. 8, no. 1, hh. 3145

[4] Damaika, et al. 2016. Kakawin Nagarakertagama: Teks dan Terjemahan. Yogyakarta: Narasi

[5] Dharmayuda, M. S. 1995. Kebudayaan Bali: Pra-Hindu, Masa Hindu, Dan Pasca Hindu [Balinese Culture: Pre-Hindu, Hindu Period, and Post Hindu]. Denpasar: Kayumas Agung

[6] Fox, R. 2015. Why Do Balinese Make Offerings? On Religion, Teleology and Complexity. Journal of the Humanities and Social Sciences of Southest Asia, hh. 29-55

[7] Geertz, C. 2017. Negara Teater: Kerajaan-Kerajaan di Bali Abad Kesembilan Belas. Negara: The Theatre State in Nineteenth-Century Bali. 1980. Yogyakarta: Basabasi

[8] Gunawan, D. H., at al. 2013. Jalan Baru Otonomi Desa: Mengembalian Otonomi Masyarakat Studi Kasus Bali, Sumatera Selatan, dan Flores [The New Road to Village Autonomy: Restoring Community Autonomy. Case Study of Bali, South Sumatra, and Flores]. Jakarta: Kemitraan Partnership

[9] Jalil, M. N. A, et al. 2019. Politico-Cultural-Religious Milieu of South East Asia: An Examination of Pre-Islamic Structures of Authority and Syncretic Practices. Journal KEMANUSIAAN, vol. 26, no. 1, hh. 109-129 
[10] Kuntowijoyo. 2013. Pengantar Ilmu Sejarah [Introduction to Historical Science]. Yogyakarta: Tiara Wacana

[11]Liefrinck, F. A. 1927. Bali an Lombok. Amsterdam: J.H. Bussy

[12] Pageh, I M. 2018. Dari Tahta Batu Ke Padmasana: Relasi Kultus Dewa Raja Dalam Pergeseran Sistem Religi Di Bali [From the Stone Throne to Padmasana: The Relationship between the Cult of Dewa Raja in the Shifting of the Religious System in Bali]. Prosiding Seminar Nasional Agama, Adat, Seni dan Sejarah Di Zaman Milenial, hh. 331-348

[13] Pitana, I G. 1994. Mosaik Masyarakat dan Kebudayaan Bali. Dalam Dinamika Masyarakat Dan Kebudayaan Bali [Balinese Culture and Society Mosaics. In the dynamics of Balinese society and culture]. (Editor: Pitana, I Gde). Denpasar: Ofset BP

[14]Purna, I M, et al. 1997. Sistem Pemerintahan Tradisional Di Bali. [Traditional Government System in Bali]. Jakarta: Cv. Putra Sejati Raya

[15] Raffles, T. S. 2014. The History of Java. Penyunting: Hamonangan Simanjuntak dan Revianto B. Santosa. Yogyakarta: Narasi

[16] Raharjo, S., et al. 1998. Sejarah Kebudayaan Bali: Kajian Perkembangan dan Dampak Pariwisata. [Cultural History of Bali: Study of the Development and Impact of Tourism] Jakarta: CV. Eka Dharma

[17] Rahman, F. 2017. Menimbang Sejarah sebagai Landasan Kajian Ilmiah; sebuah Wacana Pemikiran dalam Metode Ilmiah. [Considering History as the Basis of Scientific Study; a Discourse of Thought in the Scientific Method]. Jurnal EL-BANAT: Jurnal Pemikiran dan Pendidikan Islam, vol. 7, vol. 1, hh. 128-150

[18] Rema, N. \& Putra, I. B. R. 2018. Sumber Daya Alam Sebagai Media Literasi Di Bali. [Natural Resources as Media Literacy in Bali]. Jurnal Forum Arkeologi, vol. 31, no. 1, hh. 1-14

[19] Reuter, T. A. 2005. Custodias Of Sacred Mountains: Budaya dan Masyarakat di Pegunungan Bali. Jakarta: Yayasan Obor Rakyat

[20]Reuter, T. A. 2018. Rumah Leluhur Kami: Kelebihdahuluan dan Dualisme dalam Masyarakat Bali Dataran Tinggi. [Our Ancestral Home: Preeminence and Dualism in Highlands Balinese Society]. Jakarta: Yayasan Pustaka Obor Indonesia

[21] Sari, I. A. L., \& Putra, I N. D. 2020. Narrative on Nature Conservation: A Comparative Study of the Folktales of Bali Aga and Ainu. Journal KEMANUSIAAN, vol. 27, no. 2, hh. 59-78

[22] Sentana, G. D. D., \& Widiata, P. 2019. Pemertahan Bahasa Bali dan Konsep Tri Hita Karana dalam Struktur Pemerintahan Tradisional Ulu-Apad di Desa Sukawana Desa Pakraman Sukawana. [Understanding Balinese Language and the Concept of Tri Hita Karana in the Ulu-Apad Traditional Government Structure in Sukawana Village, Pakraman Sukawana Village]. Prosiding Konferensi Nasional "Sastra, Bahasa dan Budaya", hh. 48-52

[23] Setiawan, I K. 2017. Prasasti-Prasasti Bwahan, Kintamani, Bangli: Mengungkap Tabir Kehidupan Masyarakat Bali Kuno 1000 Tahun Yang Lalu. [Inscriptions Bwahan, Kintamani, Bangli: Revealing the Veil of Life of Old Balinese 1000 Years Ago]. Journal f Archaeology and Culture, vol. 1, no. 1, hh. 9-16

[24] Suacana. W. G. 2011. Budaya Demokrasi dalam Kehidupan Masyarakat Desa di Bali. [The Culture of Democracy in Village Community Life in Bali]. Jurnal Kajian Bali, vol. 01, no. 01, hh. 88-123

[25] Suarbhawa, I G. M. 2002. Bali Pasca Ekspedisi Gajah Mada. [Bali Post-Gadjah Mada Expedition]. Jurnal Forum Arkeologi, vol. 15, no. 1, hh. 38-47 
[26] Suwitha, I P. G. 2019. Wacana "Kerajaan Majapahit Bali”: Dinamika Puri Dalam Pusaran Politik Identitas Kontemporer. [Discourse of "Bali Majapahit Kingdom": The Dynamics of Puri in the Vortex of Contemporary Identity Politics.]. Jurnal Sejarah Citra Lekha, vol. 4, no. 1, hh. 3-14

[27] Sysling, F. 2018. Mixed messages: Racial science and local identity in Bali and Lombok, 1938-39. Journal of Southeast Asian Studies, vol. 49, no. 3, hh. 410-425

[28] Wirtawan, I W. 2013. Keberlanjutan Birokrasi Kemasyarakatan Desa Sukawana Pada Masa Bali Kuno: Kajian Berdasarkan Prasasti Sukawana D. [The Sustainability of the Community Bureaucracy of Sukawana Village in old Bali: Studies Based on the Sukawana Inscription D]. Jurnal Forum Arkeologi, vol. 26, no. 3, hh. 233 - 242

[29] Tim Penyusun Adat Istiadat Daerah Bali. 1985. Adat Istiadat Daerah Bali. [Bali Regional Customs]. Yunus Melalatoe (Editor). Denpasar: Departemen Pendidikan dan Kebudayaan

[30] Tim Peneliti dan Pencatatan Kebudayaan Daerah Bali. 1977. Sejarah Daerah Bali. [Regional History of Bali]. Denpasar: Departemen Pendidikan dan Kebudayaan

[31] Yudantini, N. M. 2018. The spatial and settlement pattern in Mabi Hamlet, Belantih Village, Kintamani: conservation of tangible and intangible of Balinese traditional architecture in Bali Aga villages. Dalam Journal IOP Conference Series: Earth and Environmental Science. 